Goldschmidt 2021 Abstract

https://doi.org/10.7185/gold2021.5626

\section{Crustal evolution of the southwestern margin of the Svecofennian Domain in the Baltic Sea region}

EVGENIA SALIN ${ }^{1}$, KRISTER SUNDBLAD ${ }^{2}$ AND STEFAN CLAESSON $^{3}$

${ }^{1}$ University of Turku

${ }^{2}$ St. Petersburg State University

${ }^{3}$ Swedish Museum of Natural History

Presenting Author: evgenia.salin@gmail.com

The Precambrian crust in the Baltic Sea area represents a southeastern extension of the Fennoscandian Shield concealed beneath the East European platform sediments. Drill core samples $(162-2600 \mathrm{~m})$ have been studied with respect to petrography, geochemistry and $\mathrm{U}-\mathrm{Pb}$ zircon geochronology (ICPMS and SIMS) in order to improve the understanding of the crustal evolution along the southwestern margin of the ca. $1.9 \mathrm{Ga}$ Svecofennian Domain. It can be presented as a sequence of younging belts from the central part of the Baltic Sea (Gotland) to the Polish coast:

1. Detrital zircons in Svecofennian metasedimentary rocks on northern Gotland record three age populations: 2.11-1.96, 2.95-2.63 Ga and 3.29 Ga, which indicate preSvecofennian sources. The lack of Svecofennian sources is not common in metasedimentary rocks elsewhere in the Svecofennian Domain.

2. A Svecofennian amphibolite-granitoid complex on central Gotland can be correlated with southern Bergslagen in the Fennoscandian Shield and the MidLithuanian Domain. It consists of $1.88 \mathrm{Ga}$ orthogneisses and amphibolites with a volcanic island arc affinity [1].

3. A km-thick sequence of ca. 1.87 Ga fluvial quartzdominated metasedimentary rocks along the Svecofennian margin are intercalated with mafic metavolcanic rocks with within-plate basalt affinity.

4. Continental margin granitoids intruded into the Svecofennian margin from southwestern Bergslagen to northwestern Lithuania. These TIB 0 granitoids were dated at $1.85 \mathrm{Ga}$ on Gotland and in E6-1 drill core, offshore Latvia [2].

5. A rifted marine volcanic arc was identified within the Vetlanda-Oskarshamn belt and was shown to be contemporaneous with the continental margin TIB 0 granitoids [3].

6. After the accretion of the volcanic arc to the Svecofennian margin, three generations of continental margin granitoids (TIB $1 \mathrm{a}-\mathrm{c}$ ) were emplaced. The 1.811.79 Ga TIB 1a granitoids intruded into Svecofennian crust and TIB 0 granitoids while the 1.79-1.77 Ga TIB $1 \mathrm{~b}$ granitoids intruded into the Vetlanda-Oskarshamn belt and the TIB 1a granitoids. Finally, the 1.77-1.75 Ga TIB 1c granitoids intruded into the TIB $1 \mathrm{~b}$ granitoids. Thus, the continental margin moved stepwise southwards from the central to southern parts of the
Baltic Sea region .

[1] Salin et al. (2019), Precamb.Res. 328, 287-308. [2] Salin et al. (2021), IJES. [3] Salin et al. (2021), Precamb.Res. 